\title{
ANTONIM DALAM AL-QURAN SURAT AL-LAIL
}

\author{
Ilham Tumanggor \\ Program Studi Pendidikan Bahasa Arab STAI As-Sunnah \\ J1. Medan-Tj. Morawa, KM 13, Gg. Darmo, Desa Bangun Sari, Kab. D. Serdang, Sumut \\ masilham90@gmail.com
}

\begin{abstract}
Abstrak Penelitian ini bertujuan untuk mengidentifikasi jenis antonimi dalam AlQuran Surat Al-Lail. Teori yang digunakan dalam penelitian ini adalah teori antonimi berdasarkan perspektif Muhammad Ali Al-Khouli. Metode yang digunakan dalam penelitian ini adalah metode deskritif-kualitatif. Data penelitian ini adalah kata, frasa dan kalimat yang menunjukkan adanya pertentangan makna (antonimi). Berdasarkan hasil penelitian jenis antonimi yang ditemukan dalam surat Al-Lail yaitu antonim mutlak/tadhod had dan antonimi bertingkat. Ayat-ayat Al-Quran memiliki lautan makna yang sangat dalam dengan gaya bahasanya yang khas. Oleh karena itu selalu ada mutiara pesan yang terkandung di dalamnya. Pada Surat Al-Lail Allah menggunakan 2 metode dalam memberi nasehat, yaitu memberikan janji akan adanya balasan/reward yang berlipat ganda dari amal kebaikan hambaNya (targhib/motivasi) dan metode tarhib (memberikan peringatan terhadap amal keburukan).
\end{abstract}

Kata Kunci: Antonimi, Al-Khouli, Al-Lail

\section{Pendahuluan}

Bahasa merupakan salah satu aspek penting dalam kehidupan bermasyarakat, penggunaan bahasa yang baik akan mendorong terjadinya proses komunikasi dan interaksi yang baik, karena bahasa merupakan salah satu alat komunikasi yang digunakan dalam kehidupan, baik secara lisan maupun tulisan.

Dari segi kebahasaan dan kesastraan, Al-Quran memiliki gaya bahasa yang khas yang sangat berbeda dengan bahasa masyarakat Arab, baik dari pemilihan huruf dan kalimat. Oleh karena itu, setiap muslim yang mentadabburi makna yang terkandung di dalamnya akan menemukan berbagai fenomena kebahasahaan, di antaranya adalah mengenai relasi makna.

Dalam setiap bahasa kita menemukan adanya hubungan kemaknaan atau relasi antonim antara satu kata dengan lainnya, atau satuan bahasa dengan satuan bahasa lainnya. Relasi antonim ini pada kenyataannya berfungsi sebagai pendekatan makna dari segi hubungan pengertian. Telah kita ketahui bahwa hubungan antara tanda yang berupa 1ntonym bunyi ujaran dengan peristiwa atau barang yang dimaksud disebut arti. 
Dalam penggunaan bahasa, setiap makna yang satu dengan makna yang lain akan memiliki hubungan yang saling ketergantungan. Di antara fenomena relasi makna adalah antonim. Antonim merupakan kebalikan dari makna sebenarnya. Pada artikel ini penulis akan membahas antonim, khususnya yang ada dalam al-Quran Surat Al-Lail.

\section{Konsep Antonimi (التضاد)}

Istilah antonimi berasal dari bahasa yunani kuno anoma "nama", dan anti "melawan". Makna harfiahnya, nama lain untuk benda yang lain. Antonim adalah ungkapan (biasanya kata, tetapi dapat juga frasa atau kalimat) yang dianggap bermakna kebalikan dari ungkapan lain. Secara mudah dapat dikatakan, antonim adalah kata-kata yang maknanya berlawanan. ${ }^{1}$

Dalam Kamus Besar Bahasa Indonesia (KBBI), kata antonim dimaknai sebagai kata yang berlawanan makna dengan kata lain, seperti kata pandai merupakan antonim dari kata bodoh. Pada kedua kata tersebut jelas terdapat makna yangbersinggungan satu sama lain yaitu kata pandai melambangkan orang yang cepat menangkap pelajaran/ilmu dan mengerti sesuatu, sedangkan kata bodoh melambangkan orangyang sulit menangkap pelajaran.

Antonimi adalah hubungan semantik antar dua buah satuan ujaran yang maknanya menyatakan kebalikan, pertentangan, atau kontras antara yang satu dengan yang lain. Misalnya kata buruk berantonim dengan kata baik, kata mati berantonim dengan kata hidup, kata guru berantonim dengan kata murid, kata membeli berantonim dengan kata menjual. ${ }^{2}$

Parera menyebutkan bahwa antonimi secara antonim dibedakan menjadi dua, yaitu pertentangan kontradiksi dan kontrer. Pertentangan kontradiksi terjadi apabila dua kata saling mengucilkan maknanya/pertentangan makna bersifat mutlak. Pertentangan kontrer adalah pertentangan yang terjadi apabila dua kata atau proposisi itu tidak mungkin samasama benar, tetapi ada kemungkinan keduanya salah. Pertentangan kontrer terbagi menjadi lima, yaitu pertentangan kenasabahan, berbalasan, jenjang, waktu, antonim. ${ }^{3}$

\footnotetext{
${ }^{1}$ Mansoer Pateda, Semantik Leksikal, (Jakarta: Rineka Cipta, 2010), hal. 207.

${ }^{2}$ Chaer, Abdul, Lingustik Umum, (Jakarta: Rineka Cipta, 2012), hal. 299.

${ }^{3}$ Parera, Teori Semantik, (Jakarta: Airrlangga, 2004), hal. 72.
} 
Pengertian yang lebih sederhana sebagaimana Verhaar mengatakan bahwa "Antonim adalah ungkapan (biasanya kata, tetapi dapat juga berupa frasa atau kalimat) yang dianggap bermakna kebalikan dari ungkapan lain."4

Dari beberapa pendapat di atas, dapat disimpulkan bahwa antonim adalah kata-kata yang maknanya berlawanan.

\section{Jenis Antonimi}

Para ahli bahasa mengklasifikasikan antonimi menjadi beberapa bagian. Di antaranya menurut A. Chaer antonimi terdiri dari:

a. Antonimi yang bersifat mutlak, seperti hidup dan mati

b. Antonimi yang bersifat antonim, seperti besar dan kecil

c. Antonimi yang bersifat relasional seperti penjual dan pembeli

d. Antonimi hieralkal seperti gram dan kilogram. ${ }^{5}$

Pada penelitian ini akan dikemukakan jenis antonim menurut Muhammad Ali Al-Khouli (ahli bahasa berkebangsaan Mesir) yang menjadi landasan teori.

1) Antonimi Mutlak (التضاد الحاد)/ Binary antonymy

Antonim mutlak, yaitu 3ntonym yang mengemukakan pertentangan makna kata-kata secara mutlak. Muhammad Ali mengatakan antonim Biner adalah antonim yang tidak menerima kata atau pemahaman ketiga. ${ }^{6}$ Artinya, kedua kata yang maknanya berlawanan itu benar-benar mutlak. Perhatikan contoh-contoh berikut:

\begin{tabular}{|c|c|}
\hline \multicolumn{2}{|c|}{ Sinonim Biner (التضاد الحاد) } \\
\hline أنثى & ذكر \\
\hline ميت & حي \\
\hline 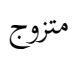 & أعزب \\
\hline امرأة & رجل \\
\hline بنت & ولد \\
\hline
\end{tabular}

Beberapa kata di atas merupakan contoh dari antonim yang bersifat mutlak. Di antaranya kata "hidup" berantonim secara mutlak dengan kata "mati",

${ }^{5}$ Ubaid Ridlo, Sinonim dan Antonim dalam Al-Quran, (Jurnal Al Bayan Vol.9, No.2,Bulan Desember Tahun 2107.ISSN 2086-9282. e-ISSN 2549-1229).

${ }^{6}$ Muhammad Ali al-Khauli, 'Ilmu ad-Dilaalah, (Urdun: Dar al-Fallah, 2001), hal. 116. 
sebab sesuatu yang masih hidup tentunya belum mati, jadi sesuatu yang sudah mati tentunya sudah tidak hidup lagi. Contoh lain, kata "lelaki" berantonim secara mutlak dengan kata "wanita", sebab seseorang yang berjenis kelamin lelaki tentu bukan wanita, dan yang berjenis kelamin wanita tentunya bukan lelaki. Antonim yang bersifat mutlak tidak akan bisa memiliki makna lain. Seperti kata "mati" dan "hidup" tidak bisa dikatakan "sangat mati" atau "sangat hidup".

2) Antonimi Relasional (التضاد العكسي)/Conversense Antonymy

Antonim relasional yaitu 4ntonym yang kedua katanya saling berhubungan. Dalam artian pertentangan yang terjadi antara objek-objek yang masih memiliki keterkaitan satu dengan yang lainnya. Perhatikan contohcontoh berikut:

\begin{tabular}{|c|c|}
\hline \multicolumn{2}{|c|}{ Antonim Relasional (التضاد العكسي) } \\
\hline 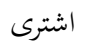 & 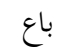 \\
\hline تعلم & علم \\
\hline ابن & أب \\
\hline 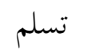 & 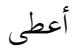 \\
\hline 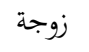 & 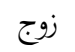 \\
\hline 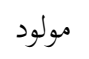 & 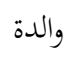 \\
\hline
\end{tabular}

Antonimi jenis ini disebut relasional karena munculnya yang satu harus disertai dengan yang lain. Adanya membeli karena adanya menjual, adanya suami karena adanya istri. Kalau salah satu tidak ada, maka yang lain juga tidak ada. Contoh konkret seorang laki-laki tidak disebut sebagai suami kalau tidak punya istri. Andai kata istrinya meninggal, maka dia bukan suami lagi, melainkan kini sudah berubah nama menjadi duda. ${ }^{7}$

3) Antonimi Bertingkat (التضاد المتدرج)/ Graded Antonymy

Syarat sebuah kata masuk dalam golongan antonimi bertingkat adalah jika suatu kata dapat dilekatkan dengan kata yang menunjukkan kualitas, maka itu bergradasi/bertingkat. Dengan kata lain, di antara medan makna pada dua

\footnotetext{
${ }^{7}$ Ibid., h. 118-119.
} 
kata yang berlawanan masih terdapat tingkatan/level. Artinya, makna dari kata-kata yang saling berlawanan masih relatif. Perhatikan contoh-contoh berikut:

\begin{tabular}{|c|c|}
\hline \multicolumn{2}{|c|}{ Antonimi Bergradasi (التضاد المتدرج) } \\
\hline صعب & 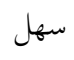 \\
\hline حار & بارد \\
\hline بعيد & قريب \\
\hline غبي & ذكي \\
\hline قبيح & 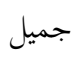 \\
\hline
\end{tabular}

Kata-kata pada tabel di atas memiliki tingkatan/level misalnya: 'sangat mudah', سهل قليل 'agak mudah. Yang menjadi pembeda dari antonim bertingkat dan mutlak adalah antonim bertingkat dapat menerima tingkatan sedangkan antonim biner tidak memliki tingkatan, seperti kata حيت 'hidup' dan ميت 'mati', tidak mungkin kata ini menerima gradasi/tingkatan seperti: حي جدا 'sangat hidup' atau ميت جدا 'sangat mati.

4) Antonimi Garis Samping (التضاد العمودي)/Vertical Antonymy

Yaitu, apabila kata-kata yang berlawanan tersebut terdiri dari kosa kata yang menunjukan arah (direction) dan kosa kata tersebut berlawanan dengan garis menyamping, sehingga disebut antonim garis samping. ${ }^{8}$ Dengan artian bahwa sifat dari antonim ini tidak satu arah. Perhatikan contoh-contoh berikut:

\begin{tabular}{|c|c|}
\hline \multicolumn{2}{|c|}{ Antonim Garis Samping (التضاد العمودي) } \\
\hline شمال \\
\hline شنوب \\
\hline غرق \\
\hline
\end{tabular}

${ }^{8}$ Ibid., h. 120. 
5) Antonimi Garis Lurus (التضاد الامتدادي) / Extensional Antonymy

Yaitu, apabila kosa kata yang berlawanan (antonim) berdasarkan garis lurus (melawan arah). Perhatikan contoh-contoh berikut:

\begin{tabular}{|c|c|}
\hline \multicolumn{2}{|c|}{ Antonim Garis Lurus (التضاد الامتدادي) } \\
\hline 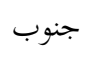 & شمال \\
\hline 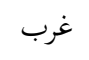 & شرق \\
\hline يمين & يسار \\
\hline تحت & 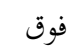 \\
\hline
\end{tabular}

6) Antonimi Sebagian (التضاد الجزئي)

Yang dimaksud dengan antonimi sebagian adalah jika kata yang saling berlawanan itu merupakan bagian darinya. Perhatikan contoh-contoh berikut:

\begin{tabular}{|c|c|}
\hline \multicolumn{2}{|c|}{ Antonimi Sebagian (التضاد الجزئي) } \\
\hline كتاب & غلاف \\
\hline 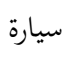 & 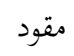 \\
\hline 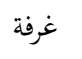 & حائط \\
\hline يد & 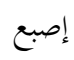 \\
\hline 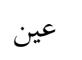 & قرنية \\
\hline
\end{tabular}

Pada contoh di atas, dapat dilihat bahwa kata-kata yang ada pada kolom kanan merupakan bagian dari kata yang berada pada kolom bagian kiri, dan kedua kata tersebut tetap memiliki perbedaan. Sampul buku tidak mungkin disamakan dengan buku, dan begitu juga sebaliknya, buku tidak bisa disamakan dengan sampulnya. ${ }^{9}$

7) Antonimi yang Berkesinambungan (التضاد الدائري)/ cyclic antonymy

Kata-kata yang termasuk dalam antonim ini saling terhubung satu sama lainnya, tetapi yang membuatnya berlawanan adalah jarak antara hari-hari tersebut. Contohnya jarak antara hari Selasa dan Sabtu, hari Sabtu terletak tiga

${ }^{9}$ Ibid., h. 121-122. 
hari sesudah hari Selasa, dan hari Selasa terletak tiga hari sebelum hari Sabtu.

Perhatikan contoh-contoh berikut:

\begin{tabular}{|c|c|}
\hline Antonimi yang Berkesinambungan (التضاد الدائري) & No \\
\hline السبت، الأحد، الإثنين، الثلاثاء، الأربعاء.، الخميس، الجمعة. & 1 \\
\hline الشتاء، الربيع، الصيف، الخريف. & r \\
\hline
\end{tabular}

8) Antonimi Berjenjang (التضاد الرتبي)/Rank Antonymy

Antonimi berjenjang merupakan kata-kata yang secara makna mengandung pertentangan, tetapi pertentangan makna ini bersifat berjenjang, bertahap, atau bertingkat. Perhatikan contoh-contoh berikut:

\begin{tabular}{|l|c|}
\hline \multicolumn{1}{|c|}{ Antonimi Berjenjang (التضاد الرتبي) } & No \\
\hline Dingin - Hangat - Panas & 1 \\
\hline Kaku - Lentur - Elastis & r \\
\hline Mahal - Wajar - Murah & 3 \\
\hline
\end{tabular}

9) Antonimi Homogen (التضاد الانتسابي)/Affinity Antonymy

Antonimi homogen merupakan kata-kata yang memiliki arti berlawanan, akan tetapi masih dalam satu rumpun yang sama. ${ }^{10}$ Perhatikan contoh-contoh berikut:

\begin{tabular}{|c|c|}
\hline Antonimi Homogen (التضاد الانتسابي) & No \\
\hline تفاح، برتقال، موز . & 1 \\
\hline بقرة، غنمة، حصان. & r \\
\hline كتاب، صحيفة، موسوعة. & 3 \\
\hline
\end{tabular}

${ }^{10}$ Ibid., hal. $125-126$. 
Muhammad Ali Al Khouli menyimpulkan bahwa secara garis besar antonimi terbagi kepada 2 (dua) macam, yaitu: kata yang berlawanan dengan satu kata/ التضاد الثنائي dan kata yang memiliki banyak lawan kata التضاد المتعدد. Pengelompokan jenis antonimi ini dapat dilahat pada gambar berikut:

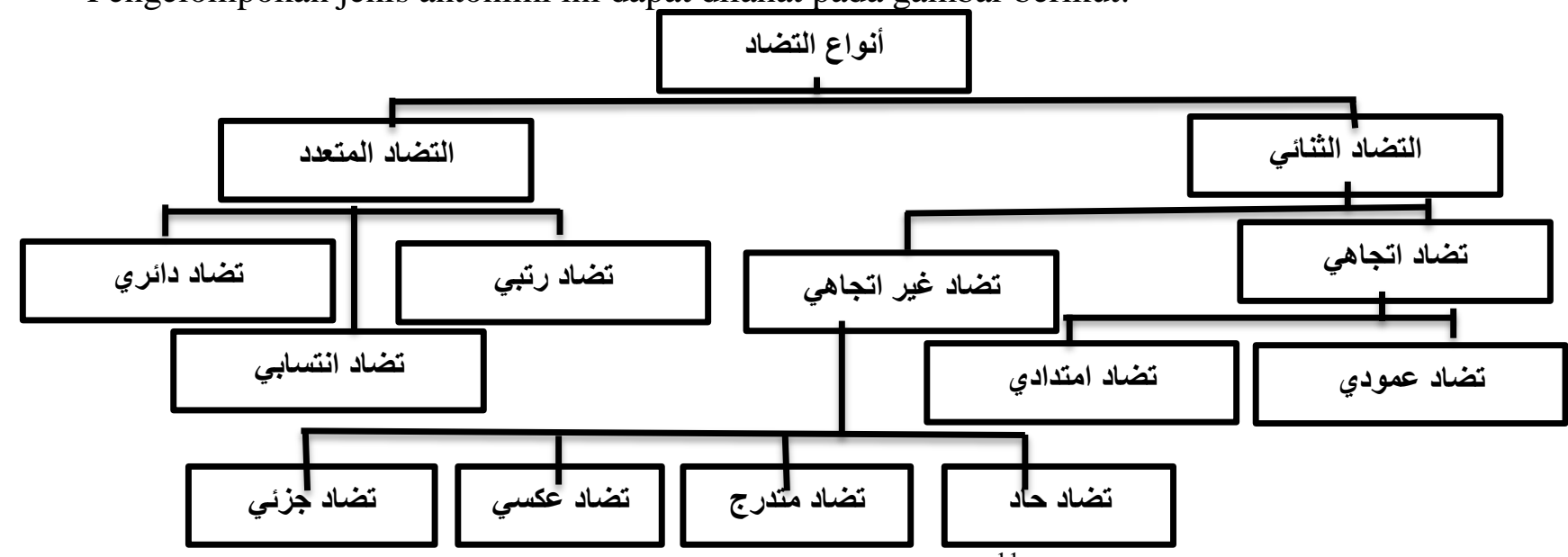

Gambar: klasifikasi jenis-jenis antonimi ${ }^{11}$

\section{Metode Penelitian}

Penelitian ini adalah penelitian studi pustaka (library research) dengan metode penelitian kualitatif deskriptif. Data dianalisis dengan menggunakan beberapa langkah sesuai teori Miles, Huberman dan Saldana (2014) yaitu menganalisis data dengan tiga langkah: kondensasi data (data condensation), menyajikan data (data display), dan menarik simpulan atau verifikasi (conclusion drawing and verification).

\section{Pembahasan}

Dalam Al-Quran surat Al-Lail, Allah de de mengawalinya dengan sumpah, yang penyebutannya diulang beberapa kali sebagai penekanan bahwa apa yang dijelaskan tentang sesuatu yang Allah bersumpah dengannya adalah benar. Dalam Surat ini Allah bersumpah dengan waktu yang terjadi di dalam segala perbuatan hamba. ${ }^{12}$ Allah yang menggunakan pasangan waktu siang dan malam, penciptaan laki-laki dan perempuan juga mengisahkan perbedaan perbuatan dan usaha manusia. Seolah menjelaskan bahwa manusia baik laki-laki atau perempuan siang atau malam selalu berusaha dan bekerja untuk menyambung

${ }^{11}$ Ibid., hal. 127.

12 As-Sa'di, Abdurrahman, Ibnu Nashir, 2006, Taisir al-Karimir Rahman Fi Tafsiri Kalamil Mannan, (Beirut: Mu'asasah ar-Risalah) hal. 1093. 
hidup di dunia dan persiapan hidup di akhirat. Segala sesuatu di alam ini diciptakan Allah dengan berpasangan. Keduanya menjadi unsur penting dalam kehidupan. Keduanya saling terkait dan berhubungan. Allah mengawalinya dengan sumpah, yang penyebutannya diulang beberapa kali sebagai penekanan bahwa apa yang dijelaskan tentang sesuatu yang Allah بلإ bersumpah dengannya adalah benar. Dalam surat ini kita dapat melihat bagaimana Allah menyampaikan pesan/nasehat kepada kita dengan janji kebahagiaan dan peringatan terhadap kesengsaraan. Kebahagiaan akan didapat oleh orang yang bertaqwa yang senantiasa mencari ridho Allah dalam setiap amalnya. Sedangkan kesengsaraan akan dirasakan oleh orang yang mendustakan akan adanya hari pembalasan serta kikir terhadap hartanya.

Sebelum menganalisis antonimi, berikut dipaparkan surat Al-Lail:

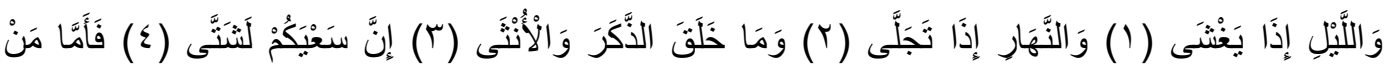

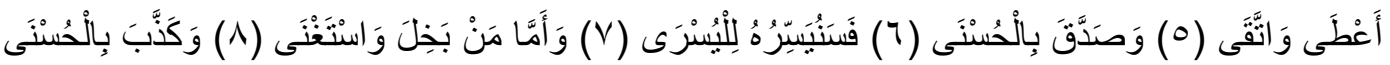

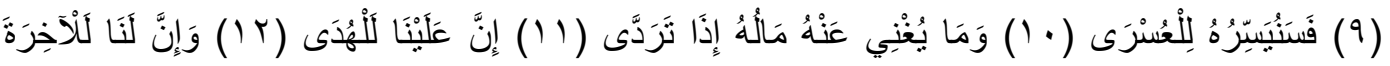

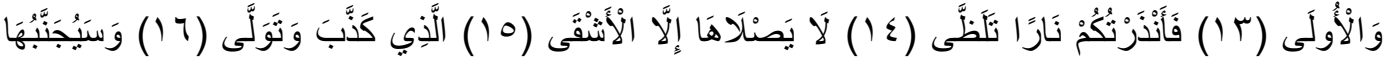

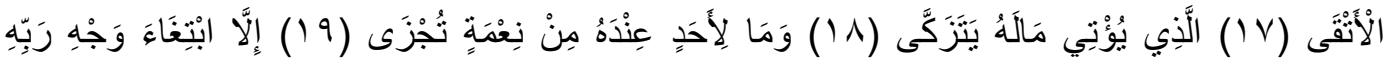

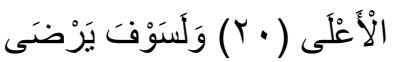

Artinya:

(1) Demi malam apabila menutupi,

(2) Demi siang apabila terang benderang

(3) Demi penciptaan laki-laki dan perempuan

(4) Sungguh, usahamu beraneka macam,

(5) Maka barang siapa memberikan (hartanya dijalan Allah) dan bertakwa,

(6) Dan membenarkan (adanya pahala) yang terbaik (surga),

(7) Maka akan kami mudahkan baginya jalan menuju kemudahan (kebahagiaan),

(8) Dan adapun orang yang kikir dan merasa dirinya cukup (tidak perlu pertolongan Allah)

(9) Serta mendustakan (pahala) yang terbaik,

(10) Maka akan kami mudahkan baginya jalan menuju kesukaran (kesengsaraan),

(11) Dan hartanya tidak bermanfaat baginya apabila binasa,

(12) Sesungguhnya kamilah yang memberi petunjuk,

(13) Dan sesungguhnya milik kamilah akhirat dan dunia ini,

(14) Maka aku memperingatkan kamu dengan neraka yang menyala-nyala,

(15) Yang hanya dimasuki oleh orang-orang yang paling celaka.

(16) Yang mendustakan (kebenaran) dan berpaling (iman).

(17) Dan aku jauhkan darinya (neraka) orang yang paling bertakwa,

(18) Yang mengingfakkan hartanya (di jalan Allah) untuk membersihkan (dirinya) 
(19) Dan tidak ada seorang pun yang memberi nikmak padanya yang harus dibalasnya

(20) Tetapi (dia memberikan itu semata-mata) karena mencari keridloan Tuhannya yang maha tinggi.

(21) Dan niscaya kelak dia akan mendapatkan kesenangan (yang sempurna).

Pada artikel ini penulis akan memaparkan antonimi antara kata dengan kata yang menunjukkan hubungan pertentangan makna antara kata dengan kata. Data penggunaan antonimi antara kata dengan kata ditemukan dalam surat Al-Lail sebagaimana dijelaskan pada table berikut:

\begin{tabular}{|c|c|c|c|}
\hline No. & Ayat & Kata berantonim & Jenis Antonim \\
\hline \multirow[t]{2}{*}{1} & \multirow{2}{*}{ 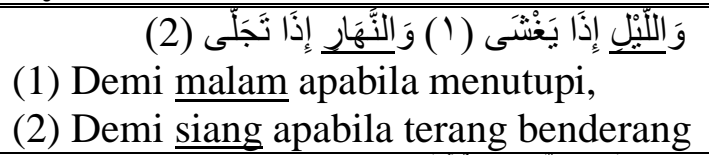 } & النهار >> اليل & Antonimi mutlak \\
\hline & & نَجَلْى >> > يَغْشَى & Antonimi mutlak \\
\hline 2 & 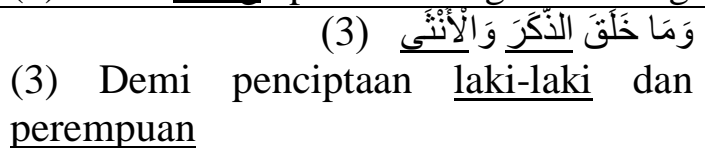 & الأنتى >> الذكر & Antonimi mutlak \\
\hline 3 & 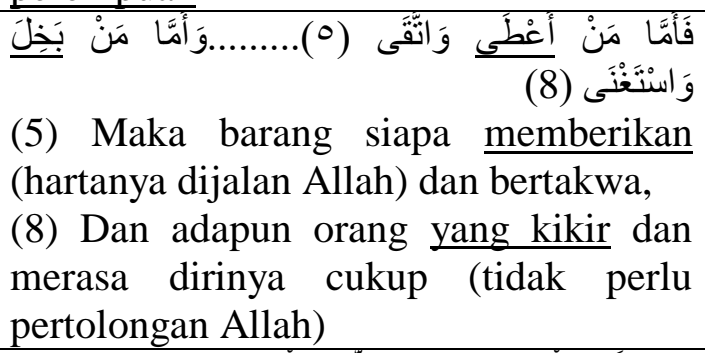 & بخل >> أعطى & Antonimi mutlak \\
\hline 4 & 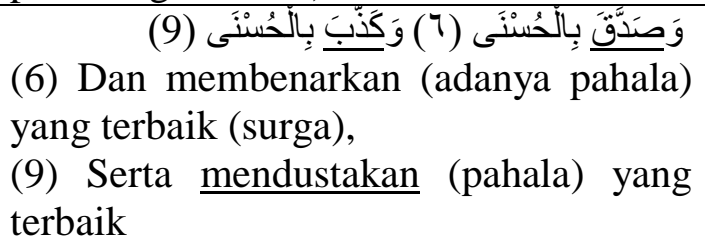 & كذّب >> صدّق & Antonimi mutlak \\
\hline 5 & 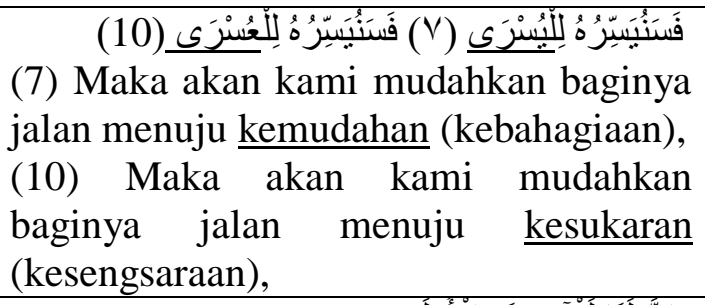 & العسرى >> اليسرى & Antonimi bertingkat \\
\hline 6 & $\begin{array}{l}\text { (13) Dan sesungguhnya milik kamilah } \\
\text { akhirat dan dunia ini, }\end{array}$ & 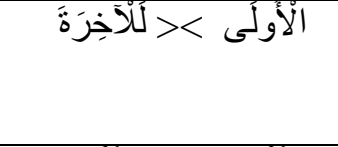 & Antonimi mutlak \\
\hline 7 & 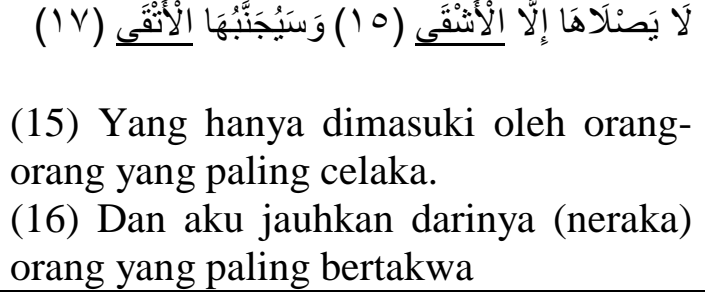 & 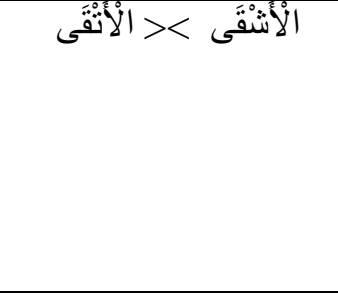 & Antonimi mutlak \\
\hline
\end{tabular}




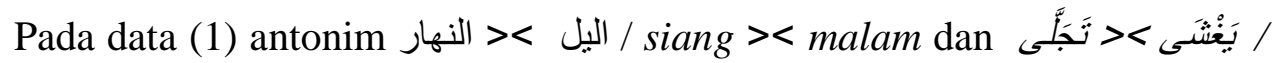
menutupi (gelap) $><$ terang merupakan antonimi mutlak, karena pertentangan makna pada kedua kata tersebut bersifat mutlak. Pertentangan makna kata siang dan malam Allah rincikan dengan peristiwa yang jauh berbeda pada dua waktu ini, yakni pada siang hari kondisi bumi terang benderang dan pada malam hari kondisi menjadi gelap.Pada data (2) antonim الأكر > > الأنثى /perempuan >lakilaki juga merupakan antonimi mutlak, karena seseorang yang berjenis kelamin lelaki tentu bukan wanita, dan yang berjenis kelamin wanita tentunya bukan lelaki. Data selanjutnya kata بخل أعطى > memberi (dermawan) merupakan jenis antonimi mutlak karena orang yang kikir sudah pasti bukan orang yang suka memberi/dermawan. Antonim صدّق<> كذّب /mendustakan > membenarkan juga merupakan antonimi mutlak. Dua kata ini memiliki pertentangan makna yang jauh; orang yang mendustakan akan adanya pahala/balasan berakibat tidak mau beriman dan beramal sholeh sehingga kelak akan dimasukkan ke dalam neraka. Sedangkan orang yang membenarkan/meyakini akan adanya pahala/balasan akan mendorongnya untuk beriman dan beramal sebanyak-banyaknya sehingga kelak akan dimasukkan kedalam surga.

Pada data (5) terdapat antonim العسرى >> mudah > sulit merupakan jenis antonimi bertingkat, karena kata mudah dan sulit memiliki tingkatan/level. Hal ini dapat dibuktikan dengan menambahkan kata "sangat, lumayan, dan lainnya" pada kedua kata tersebut, 'sangat mudah'. Data selanjutnya (6) antonim

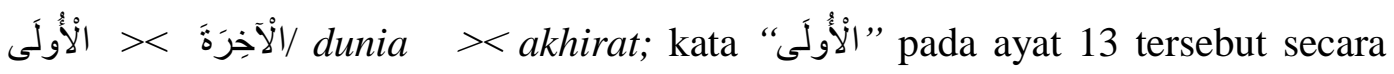
harfiyah diartikan 'permulaan', akan tetapi ditafsirkan dengan kata 'dunia' karena dunialah yang pertama-pertama akan dijalani oleh manusia. Pada data (7) antonim

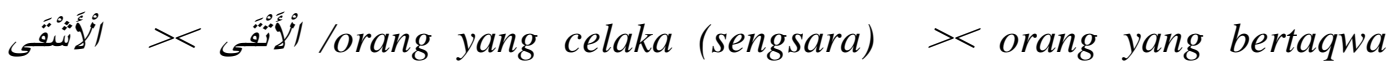
merupakan jenis antonimi mutlak. Secara makna harfiyah tidak terlihat pertentangan makna, akan tetapi pada hakikatnya pada dua kata tersebut terjadi pertentangan makna yang membandingkan kata taqwa dengan dampak yang diakibatkan bila tidak bertaqwa, yakni kesengsaraan.

Secara umum pertentangan makna antara kata dengan kata atau antara kalimat dengan kalimat pada surat ini jelas terlihat. Setidaknya ada dua topik/tema yang 
Allah bandingkan dalam surat ini. Yang pertama kandungan makna pada ayat 1-4 bahwa sudah merupakan sunnatullah banyak hal yang diciptakan berpasangan, seperti siang dan malam, terang dan gelap, lelaki dan perempuan. Hal ini menunjukkan masing-masing sudah Allah atur fitrahnya dengan sangat sempurna. Hal ini seharusnya dapat menjadi perenungan oleh setiap insan akan Kebesaran Sang Pencipta. Yang kedua pada ayat 5-21 Allah membandingkan dua kondisi manusia dalam menjalani kehidupan di dunia ini dan kelak balasan yang akan didapat. Kondisi orang yang mengimani/percaya akan adanya balasan/pahala dari setiap apa yang diamalkan akan giat melakukan sedekah dan amal sholih sehingga ia akan mendapatkan kemudahan di dunia dan akhirat yang pada akhirnya akan dimasukkan ke dalam surga (kebahagiaan abadi). Sedangkan orang yang mendustakan akan adanya hari pembalasan maka ia akan kikir terhadap hartanya dan merasa tidak butuh siapa-siapa lagi akan mendapat balasan kesengsaraan di dunia dan di akhirat yang akan dimasukkan ke dalam neraka.

\section{Simpulan}

Jenis antonimi yang ditemukan dalam surat Al-Lail yaitu antonim mutlak/tadhod had, antonimi bertingkat. Ayat-ayat Al-Quran memiliki lautan makna yang sangat dalam, oleh karena itu selalu ada mutiara pesan yang terkandung di dalamnya. Pada Surat Al-Lail Allah menggunakan 2 metode dalam memberi nasehat, yaitu memberikan balasan/reward yang berlipat ganda dari amal kebaikan hambaNya (targhib/motivasi) dan metode tarhib (memberikan peringatan terhadap amal keburukan). Dua metode ini sangat sesuai dengan fithrah manusia dalam menjalankan perintah Allah dan meninggalkan larangan. Hal ini juga sekaligus mengajarkan kepada setiap pendakwah/penceramah untuk tidak melulu menyampaikan fadhail/keutaman-keutamaan suatu amal kebaikan tapi juga harus diimbangi dengan menyampaikan ancaman/bahaya bagi orang yang melanggar perintah Allah. 


\section{Pustaka Acuan}

Al-Khauli, Muhammad Ali. 2001. I'lmu ad-Dilaalah. Urdun: Dar al-Fallah, 2001. As-Sa'di, Abdurrahman Ibnu Nashir. 2006. Taisir al-Karimir Rahman Fi Tafsiri Kalamil Mannan. Beirut: Mu'asasah ar-Risalah.

KBBI, 2019. Kamus Besar Bahasa Indonesia (KBBI). [Online]. Available at: https://kbbi.kemdikbud.go.id.

Kementerian Agama RI. 2009. AL-Quran dan Terjemahnya. Depok : PT Sabiq.

Mansoer Pateda. 2010. Semantik Leksikal. Jakarta: Rineka Cipta.

Chaer, Abdul. 2012. Lingustik Umum. Jakarta: Rineka Cipta. 1995. Pengantar Semantik Bahasa Indonesia, Jakata: RinekaCipta

Parera. 2004. Teori Semantik. Jakarta: Airrlangga, 2004.

Ubaid Ridlo, Sinonim dan Antonim dalam Al-Quran, (Jurnal Al Bayan Vol.9, No.2, Bulan Desember Tahun 2107.ISSN 2086-9282. e-ISSN 2549-1229).

Verhaar, J.W.M. (2012). Asas-Asas Linguistik Umum. Yogyakarta: Gadjah Mada University Press. 